\title{
Nutritional Status of Settler and Indigenous Women of Reproductive Age Group in Khagrachari District, Bangladesh
}

\author{
Md Monoarul Haque ${ }^{1}$, Jesmin Akter ${ }^{2}$, Kazi Rumana Ahmed ${ }^{3}$, Hasina Akhter Chowdhury ${ }^{4}$, \\ Sharmin Hossain ${ }^{5}$, Nantu Bikash Tripura ${ }^{6}$ \\ Received: September 10, 2013 Accepted: January 2, 2014
}

\begin{abstract}
Background: Reproductive health is closely related with nutritional status of a country. Women are regarded as the nerve centers of the families and society, maternal nutrition and health is considered as the most important regulator of human fetal growth. Objective: This study was conducted with a view to assess the nutritional status of settler and indigenous women of reproductive age group (15-49 years) in Khagrachari district. Materials and Methods: This cross sectional study was done in the purposively selected Panchari thana of Khagrachari district in Bangladesh from 01 May to 31 August 2013. A total of 200 reproductive aged women were interviewed. Among them 100 were indigenous and 100 were settlers. Their anthropometric measurements were taken and nutritional status was determined by body mass index (BMI) recommended by World Health Organization (WHO) for Asian people. Results: The mean age of the respondents was $29.8 \pm 11.1$ years and maximum were in the age group of 15-24 years. Among the indigenous subjects Chakma, Marma, Tripura and Boisnu were 20.5\%, 20.5\%, 6.5\% and 2.5\% respectively. Among 100 indigenous reproductive aged women 17 were underweight; but among settlers 19 were underweight. Forty nine settler women were normal and in case of indigenous women 46 were normal. But regarding overweight indigenous women went ahead than settler women and obesity was found equal in both groups. Mean difference of mid upper arm circumference $(M U A C)$ was significantly different $(p<0.005)$ between the groups. Conclusion: This study provided a vivid picture of the nutritional status of the settler and indigenous reproductive aged women.
\end{abstract}

Key words: Nutritional status; Reproductive age; Indigenous women

\section{Introduction}

J Enam Med Col 2014; 4(2): 98-101

Maternal nutritional status is important for a host of reasons for the woman herself, for her capacity to reproduce, and for the development of her children, with implications for the health and reproductive capacity of the next generation's mothers. However, for decades, issues in women's nutrition have centered on nutrition during pregnancy and lactation. Much of the concern has thus been for the newborn's health and well-being. ${ }^{1}$ Only recently has attention been paid to the link between women's own nutritional and health status and their multiple roles in family and society. Several reviews have

1. Fellow, Department of Community Nutrition, Bangladesh University of Health Sciences (BUHS), Dhaka

2. Lecturer, Department of Reproductive and Child Health, Bangladesh University of Health Sciences (BUHS), Dhaka

3. Assistant Professor, Department of Health Promotion \& Health Education, Bangladesh University of Health Sciences (BUHS), Dhaka

4. Lecturer, Department of Biostatistics, Bangladesh University of Health Sciences (BUHS), Dhaka

5. Lecturer, Department of Health Promotion \& Health Education, Bangladesh University of Health Sciences (BUHS), Dhaka

6. Medical Officer, Dr. M. A. Rahman Hospital, Golapgonj, Sylhet

Correspondence Md Monoarul Haque, Email: monoarmunna@yahoo.com 
emphasized the vulnerability of women throughout their life cycle. ${ }^{2-4}$ Reproductive health is closely related with nutritional status of total population of a country. Adequate nutrition is a prerequisite for attaining good health, quality of life, and national productivity. Nutritional problems are different between developed and developing countries. The socioeconomic, health and nutritional status of women depict gloomy pictures throughout their lives. Besides, like most developing countries, the picture of nutritional status of women is far too serious in the poorer socioeconomic groups who live in the rural areas and urban slums of Bangladesh. It is wellestablished that infants, children and women of the reproductive age constitute the most vulnerable groups from the standpoint of nutrition. Based on dietary and anthropometric results, some studies showed that malnutrition is a common feature among low income rural women, but this type of information in hilly area is rare. ${ }^{5}$ Tribal population in Bangladesh is living in different ecosystems and depends on primitive agricultural practices; they often face uncertainty of food supply and tend to suffer from undernutrition. Malnutrition in different grades (underweight, wasting, stunting) among women of reproductive age in hilly area is an alarming threat through life. There is very little information about the nutritional status of these women living in hilly area. Hence to fill up some of this information gap, the present study was carried out to assess the nutritional status of these women in hilly area.

\section{Materials and Methods}

This cross sectional study was conducted on 200 women, both indigenous and settlers, aged 15-49 years in Panchari thana of Khagrachari district in Bangladesh from 01 May to 31 August 2013. This area and the study subjects were purposively selected to get adequate sample. Nonprobability purposive sampling method was used for data collection. Sick women, women with sick babies, mentally retarded and insane women were excluded from the study. Nutritional status was determined by body mass index (BMI) recommended by World Health Organization (WHO) for Asian people. 6 For anthropometric measurements, height was measured with a standiometer, body weight was measured using a platform beam scale and mid upper arm circumference (MUAC) was measured using non- stretch, non-elastic measuring tape. In case of height and MUAC, three measurements were taken three times and if the difference among readings was less than $1 \mathrm{~cm}$, the mean measurement was taken and recorded to the nearest $0.1 \mathrm{~cm}$. If the reading fell between two values, the lower reading was recorded. Weight was recorded to the nearest $0.1 \mathrm{~kg}$. Nutritional status was also evaluated based on internationally recommended ${ }^{7}$ cut-off points for MUAC, according to which MUAC under $22.0 \mathrm{~cm}$ indicates undernutrition and $\geqslant 22.0 \mathrm{~cm}$ indicates normal nutritional status. The socio-economic classification in this study was made according to 2006 Gross National Income (GNI) per capita and using the calculation of World Bank (WB). ${ }^{8}$ The groups were low-income $\$ 75.41$ or less (BDT $\leqslant 5360$ ), lower middle-income \$75.5-\$299.58 (BDT 5361-21270), upper middle-income \$299.68$\$ 926.25$ (BDT 21271-65761) and high-income $\$ 926.33$ or more $(\mathrm{BDT} \geqslant 65762)$. Before data collection, permission was taken from the Headman/Karbari from each ethnic community. All the tribal people were informed about the study and different local language interpreters from different ethnic communities were selected to translate questionnaire. Data were collected using pretested semistructured questionnaire by face to face interview. Information about nutritional status along with socio-demographic characteristics was also obtained. After collection, data were sorted, scrutinized according to the selection criteria and then data were analyzed by SPSS version 12.0 program. Data were analyzed by descriptive and inferential statistics.

\section{Results}

The mean age of the respondents was $29.8 \pm 11.1$ years and maximum number of the subjects were in the age group of 15-24 years. Among the study subjects $70.5 \%$ were married, $30 \%$ were housewives, $26 \%$ were students and $12 \%$ were engaged in agriculture. Among the respondents 35\% were from lower income group (BDT $\leqslant 5360$ ), $58.5 \%$ from lower middle income group (BDT 5361-21270) and $6.5 \%$ were from upper middle income group (BDT 21270-65761). Among the respondents $41.5 \%$ were illiterate, 26\% completed primary level and 25.5\% completed secondary level of education. Chakma, Marma, Tripura, Boisnu were 20.5\%, 20.5\%, 6.5\%, $2.5 \%$ respectively and $50 \%$ were settlers (Table I). 
Among 100 reproductive aged women in indigenous group 17 were underweight, 46 were normal, 22 were overweight and 15 were obese (Fig 1). Among 100 settlers 19 were underweight, 49 were normal, 17 were overweight and 15 were obese (Fig 1). In the settlers group, mean \pm SD of height, weight, BMI and MUAC were $153.2 \pm 8.5 \mathrm{~cm}, 53.1 \pm 12.6 \mathrm{~kg}$, $22.4 \pm 4.4$ and $24.7 \pm 2.9 \mathrm{~cm}$ and those in indigenous group were $154.8 \pm 9.8 \mathrm{~cm}, 55.5 \pm 14.1 \mathrm{~kg}, 23.2 \pm$ 6.6 and $25.9 \pm 3.4 \mathrm{~cm}$ respectively. Mean difference of MUAC was significant $(\mathrm{p}<0.005)$ between groups (Table II).

Table I: Distribution of the respondents by their socio-demographic characteristics $(n=200)$

\begin{tabular}{|c|c|c|}
\hline Variables & Number & Percentage \\
\hline \multicolumn{3}{|l|}{ Age (in years) } \\
\hline $15-24$ & 75 & 37.5 \\
\hline $25-34$ & 50 & 25 \\
\hline $35-44$ & 39 & 19.5 \\
\hline$\geqslant 45$ & 36 & 18 \\
\hline Mean $\pm \mathrm{SD}$ & \multicolumn{2}{|c|}{$29.8 \pm 11.1$} \\
\hline \multicolumn{3}{|l|}{ Education } \\
\hline No schooling/illiterate & 83 & 41.5 \\
\hline Primary & 52 & 26 \\
\hline Secondary & 51 & 25.5 \\
\hline Higher-secondary \& above & 14 & 7 \\
\hline \multicolumn{3}{|l|}{ Occupation } \\
\hline Housewife & 60 & 30 \\
\hline Agriculture & 24 & 12 \\
\hline Student & 52 & 26 \\
\hline Others & 64 & 32 \\
\hline \multicolumn{3}{|l|}{ Ethnicity } \\
\hline Chakma & 41 & 20.5 \\
\hline Marma & 41 & 20.5 \\
\hline Tripura & 13 & 6.5 \\
\hline Boisnu & 5 & 2.5 \\
\hline Settlers & 100 & 50 \\
\hline \multicolumn{3}{|l|}{ Monthly income (BDT) } \\
\hline Lower income $(\leqslant 5360)$ & 70 & 35 \\
\hline $\begin{array}{l}\text { Lower middle income } \\
(5361-21270)\end{array}$ & 117 & 58.5 \\
\hline $\begin{array}{l}\text { Upper middle income } \\
(21271-65761)\end{array}$ & 13 & 6.5 \\
\hline \multicolumn{3}{|l|}{ Marital status } \\
\hline Single & 59 & 29.5 \\
\hline Married & 141 & 70.5 \\
\hline
\end{tabular}

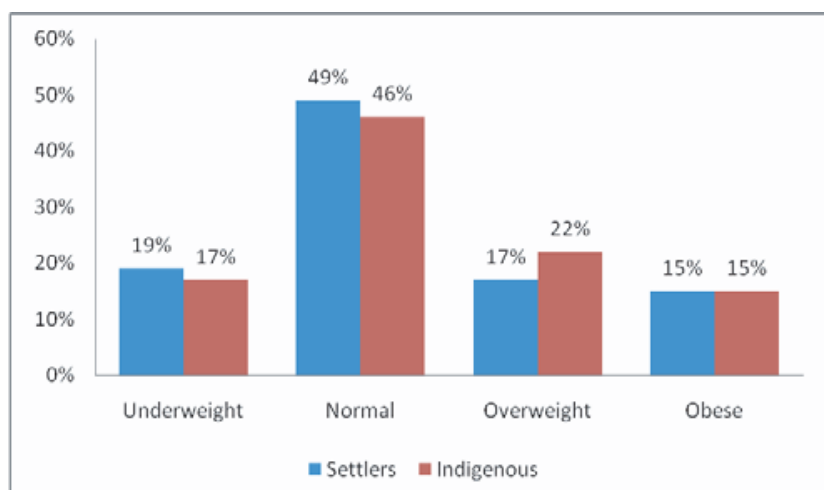

Fig 1. Nutritional status of study subjects $(n=200)$

Table II: Anthropometric characteristics of the respondents $(n=200)$

\begin{tabular}{|l|c|c|c|} 
Variables & \multicolumn{3}{|c|}{ Anthropometric characteristics } \\
& $\begin{array}{c}\text { Settlers } \\
(\mathrm{n}=100)\end{array}$ & $\begin{array}{c}\text { Indigenous } \\
(\mathrm{n}=100)\end{array}$ & $\mathrm{p}$ value \\
\hline Height $(\mathrm{cm})$ & $153.2 \pm 8.5$ & $154.8 \pm 9.8$ & $0.584^{\mathrm{NS}}$ \\
\hline Weight $(\mathrm{kg})$ & $53.1 \pm 12.6$ & $55.5 \pm 14.1$ & $0.926^{\mathrm{NS}}$ \\
\hline BMI & $22.4 \pm 4.4$ & $23.2 \pm 6.6$ & $0.102^{\mathrm{NS}}$ \\
\hline MUAC $(\mathrm{cm})$ & $24.7 \pm 2.9$ & $25.9 \pm 3.4$ & 0.004 \\
\hline
\end{tabular}

$N S=$ Not significant

\section{Discussion}

Nutritional status is the result of complex interactions of food consumption, overall health status and health care practices. Poor nutritional status is one of the most important health and welfare problems which are faced by Bangladesh.

The present study showed that majority of the respondents $(37.5 \%)$ were from 15-24 years age group. The study conducted by Haque et $\mathrm{al}^{9}$ showed that among reproductive aged women of slums, a large number of respondents $(41.2 \%)$ were in the age group of 15 to 24 years. In their study majority of the respondents (62.7\%) and their husbands (67\%) were illiterate, but in present study it was found that $41.5 \%$ respondents were illiterate, $26 \%$ and $25.5 \%$ completed primary and secondary level of education. Haque et $\mathrm{al}^{9}$ found that $57 \%$ of the respondents were housewives and most of the working women were garment workers $(33 \%)$; but in present study $30 \%$ were housewives, $26 \%$ students and $12 \%$ were engaged in agriculture. The average monthly income of the respondents was Tk. $3056.9 \pm 981.8$ in their study whereas in this study most of the respondents 
were from lower middle income group (Tk. 536121270). The present study found that about $50 \%$ of the reproductive aged women in both groups had normal nutritional status whereas $17 \%$ of indigenous women and $19 \%$ of settler women were underweight. But regarding overweight indigenous women went ahead than settler women and obesity was found equal in both groups. One study showed that almost $58.0 \%$ of the women had normal weight and nearly $14.0 \%$ were overweight. ${ }^{10}$ Another study showed that a total of $34 \%$ of the reproductive aged rural women suffer from malnutrition ${ }^{11}$ and two studies conducted among tribal groups of India found that high prevalence of undernutrition was still present there which influences health and nutritional status in nonsatisfactory level. ${ }^{12,13}$ These findings suggest that both underweight and overweight or obesity coexist in the reproductive aged settler and tribal women in Bangladesh.

In this study the mean height, weight and BMI were almost same among the women of both groups, but the mean difference of MUAC was significantly different between groups. In a study conducted among tribal women in India it was found that the mean height, weight, MUAC, and BMI of the subjects were $149.25 \mathrm{~cm}, 40.98 \mathrm{~kg}, 21.60 \mathrm{~cm}$ and 18.33 respectively. ${ }^{14}$ On the other hand, another study conducted in settler women in Bangladesh found that the mean weight, height and BMI were $47.4 \pm 9.7 \mathrm{~kg}, 150.4 \pm 6.4 \mathrm{~cm}$ and $21.0 \pm 5.0$ respectively. ${ }^{10}$

In this study overall nutritional status among the settlers and tribal population in Khagrachari area of Bangladesh was found similar and acceptable; but if we see the nutrition profile in Bangladesh, malnutrition among women is extremely prevalent. This study provided a vivid picture of the nutritional status of the hilly women, both settlers and indigenous, in their reproductive age. However, large scale interventional study is needed for this particular group of subjects in this area.

\section{References}

1. Shepard MJ, Bakketeig LS, Jacobsen G, O'Connor T, Bracken MB. Maternal body mass, proportional weight gain, and fetal growth in parous women. Paediatr Perinatal Epidemiol 1996; 10: 207-219.
2. Leslie J. Women's nutrition: the key to improving family health in developing countries? Health Pol Plan 1991; 6(11): 1-19.

3. Tinker A, Daly P, Green C, Saxenian H, Lakshminarayanan R, Gill K. Women's health and nutrition. World Bank Discussion Paper No. 256. Washington, DC: World Bank, 1995.

4. Merchant KM, Kurtz KM. Women's nutrition through the life cycle: social and biological vulnerabilities. The health of women: a global perspective, Boulder, Colorado, Westview Press, 1993: 63-90.

5. Islam MZ, Akhtaruzzaman M, Lamberg-Allardt C. Nutritional status of women in Bangladesh: comparison of energy intake and nutritional status of a low income rural group with a high income urban group. Asia Pac J Clin Nutr. 2004; 13(1): 61-68.

6. WHO expert consultation. Appropriate body-mass index for Asian populations and its implications for policy and intervention strategies. Lancet 2004; 363: 157-163.

7. James WPT, Mascie-Taylor CGN, Norgan NG, Bristrian BR, Shetty P, Ferro-Luzzi A. The value of arm circumference measurements in assessing chronic energy deficiency in third world adults. Eur J Clin Nutr 1994; 48: 883-894.

8. Haque ANMN. The middle-income matrix. The Daily Star, November 18, 2007.

9. Haque MJ, Rashid M. Nutritional status of the women of reproductive age with some of their sociodemographic characteristics of a slum in Dhaka. Dinajpur Med Col J 2009; 2(1): 2-7.

10. Mostofa SM, Islam A. Socio-economic correlates of malnutrition among married women in Bangladesh. Mal J Nutr 2010; 16(3): 349-359.

11. Milton AH, Smith W, Rahman B, Ahmed B, Shahidullah SM, Hossain Z et al. Prevalence and determinants of malnutrition among reproductive aged women of rural Bangladesh. Asia Pac J Public Health 2010; 22(1): 110-117.

12. Bhasin MK, Jain S. Biology of the tribal groups of Rajasthan, India: body mass index as an indicator of nutritional status. Anthropologist 2007; 9(3): 165-175.

13. Patel R. Comparative study of health, nutrition and hygiene among the Jaunsari tribe of Uttarakand State and the Nicobarese of Tsunami-affected Car Nicobar island in India [Abstract]. 13 ${ }^{\text {th }}$ Annual Scientific Conference, ICDDR,B 2011: 116.

14. Bisai S, Bose K. Undernutrition in the Kora Mudi tribal population, West Bengal, India: a comparison of body mass index and mid-upper-arm circumference. Food and Nutrition Bulletin 2009; 30(1): 63-67. 